\title{
Saudis warm to solar energy
}

\section{Even Saudi Arabia is searching for new sources of energy. Here Ziauddin Sardar reports on the Saudi approach to the sun}

SOlar energy has arrived in Saudi Arabia; and in keeping with the Saudi style, has arrived in a big way.

Two factors are responsible for the current upsurge in solar energy activities in the Kingdom. The first is the swish, aggressive, sales techniques of the French, Swiss and American solar energy salesmen. The Saudi could hardly resist such tactics. But the second is a genuine desire for developing alternative energy sources.

The Saudis well appreciate that oil wells have a finite life; twenty, thirty years at the most. This realisation has been articulated by more than one Saudi minister; and recently it even received royal approval from Crown Prince Fahd. Opening a meeting of the governing board of the Arab Bank for Economic Development in Africa, Prince Fahd said that Saudi Arabia "continues honestly and truthfully to provide the required output of oil and gas because it feels it shares a responsibility with other nations towards the international community. But our feelings of responsibility towards the coming generations in Saudi Arabia require us to look at the situation carefully and to try to balance current requirement with future needs". $\mathrm{He}$ went on to say that while it is recognised that oil should be conserved "we are anxious because world consumption of energy is rising at a time when the interest of oil producing countries, as well as of consuming nations, requires stringent measures to cut down consumption and find alternative sources".

Saudi Arabia itself has chosen to back the solar energy alternative, with the accent on achieving solar energy self-sufficiency by the year 2000 . Saudi solar energy enthusiasts argue that the Kingdom is even richer in the sun than it is in oil.

Being mostly desert, Saudi Arabia has one of the highest insolations in the world. The Kingdom receives some $3500-4000$ hours of sunshine and the average yearly solar intensity is about $550 \mathrm{cal} / \mathrm{cm}^{2} /$ day. It has argued at the recently held first Solar Energy Conference (King Abdulaziz University, Jeddah, 21-23 January) that this energy can be tapped to distill brackish water for drinking and agriculture, generate power, cook food and dry crops. The extreme variations in climate during the day and night can lead to the application of passive cooling during the summer. Geothermal energy in some parts of the Kingdom as well as greenhouse technology can make Saudi Arabia self-sufficient in energy and food.

Probably the single most important outcome of the conference, which was attended by 119 international scientists, was the formation of the Saudi Solar Energy Commission. Lead by Dr Fawaz Alamy, Vice Dean of College of Engineering, King Abdulaziz University, the commission is entrusted with coordination and encouragement of solar energy research in the Kingdom.

Solar research activities in the Kingdom have been pioneered by the University of Riyadh where studies in heating and air-conditioning applications of solar energy have now been conducted for over a decade. Other research activities include solar clectronic power generation at the University of Petroleum and Minerals

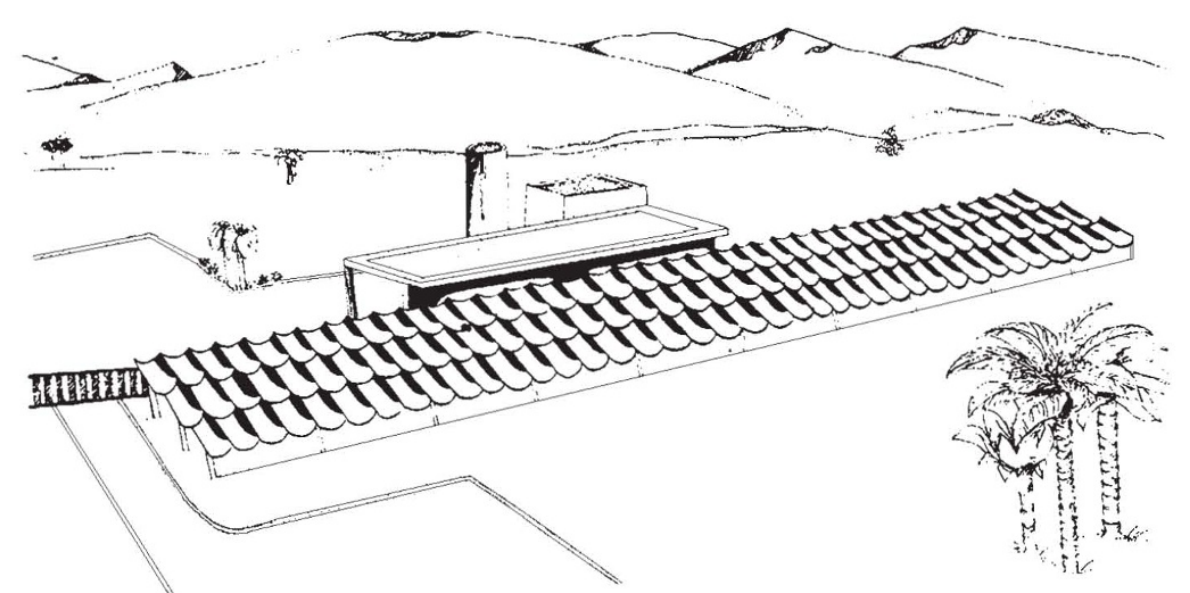

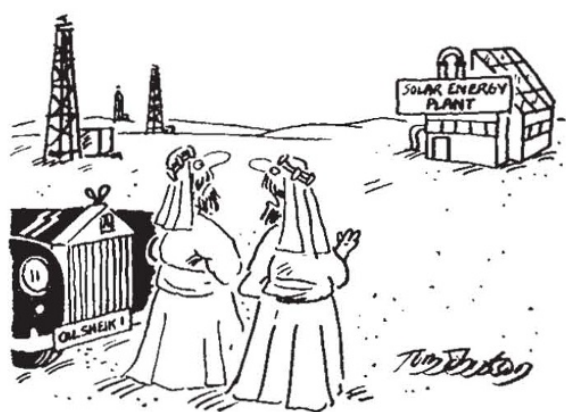

"I hope it's just a mirage"

in Dahran; agricultural and industrial applications of solar energy at the King Faisal University, Dammam; and water desalination research at the King Abdulaziz University, in Jeddah.

In addition to the solar energy commission, a Saudi Technology and Research Consulting Centre (STAR) has been set up. It will be largely concerned with the applications of solar energy in air-conditioning, heating, agriculture, electricity generation, weather modification and industry. The centre's first task was to award a grant of five million Australian dollars to Sydney University's Science Foundation for Physics for solar energy research. Prince Nawafibn Abdul Aziz, Chairman of the centre, has already presented a cheque for the initialA $\$ 3.5$ million to the foundation. The second and final instalment of A\$1.5 million will be made in 18 months.

Saudi Arabia has also resolved to encourage solar energy conciousness in other countries. Mr Tarek Al-Akeel of Saudi Arabia's Al-Dariyyah Institute told the delegates at the recently held Soltech exhibition in Bahrain: "The objectives of the Al-Dariyyah Institute are twofold: to encourage the development of solar energy for third world people, who suffer from increases in fossil fuel and food prices, and to encourage industrialised countries to conserve fossil fuel energy so all mankind can be served equally". The Institute has invested US $\$ 850,000$ in the Terraset School near Washington D.C. which investigates ways of making future buildings energy efficient and solar energy more economic; and US $\$ 100,000$ in a consciousnessraising cartoon film which will be aired on bought television spots. This is seen as "indirect encouragement" for the conservation of fossil reserves and promotion of solar energy.

In the Kingdom itself, there are four main solar energy projects nearing completion:

- The first reflects the Saudi style of doing things. It is the solar space and water heating system at the Airborne and Physical Training School, King Abdulaziz Military cantonment, Tabuk, 
being constructed by Sverdrup and Parcel of St. Louis, Missouri, which is the largest solar energy plant in the worid. With some $5,000 \mathrm{~m}^{2}$ of collectors, the plant in the system supplies $70 \%$ of the total heat load by solar energy. The price tag has a pay back of 20 years; with the replacement of parts included in the cost-analysis. Sverdrup and Parcel claim that the system should be usable for a total of 30 to 35 years. Perhaps!

- The second, a more modest plant, is being developed in Riyadh by Safretes of France. With $6,000 \mathrm{~m}^{2}$ of collectors, the system is designed to produce an output of $45 \mathrm{~kW}$ of power. - A similar third plant is being developed by SOTEC of Switzerland for King Abdulaziz University in Jed- dah. The project is designed to familiarise students with unconventional seawater desalination method based on solar energy. A solar collector farm will be linked to a multistage flush evaporator for the production of fresh water.

- The fourth project is perhaps the most interesting for it is concerned with the supply of power to small villages in remote places. Normally such villages are supplied by local power stations using diesel engines of sizes varying between $200-2,000 \mathrm{~kW}$. The Kingdom's electricity corporation has decided to replace these stations by thermodynamic conversion solar stations with flat plate collectors. Although it is recognised that solar cells are expensive and any device using them will ordinarily be prohibitive, all considerations of cost have been displaced by the desire to solve the "problems" of the people living in desert areas. The prototype system, which will be used as a research and development centre for solar power plants, is to be designed by Safretes.

It is debatable whether, in the long run, anything lasting can be achieved by such conspicuous projects and flow of capital. The Saudis are quite content with buying off-the-shelf technology-which makes nonsense of all the talk of future self-sufficiency. Not everyone is impressed, however. As one prominent Saudi scientist said at Soltech, "Its all very well to bring this equipment home and play around with it. But don't call that research".
WhEN Adam and Eve were driven out of the Garden of Eden, they were told: "By the sweat of thy face shalt thou eat bread", the implication was that they would have to work very hard to obtain enough food to survive. This text from the book of Genesis has convinced most people that the life of early man was one of endless toil. They also assume that the same is true for the members of tribes living today whose way of life is usually considered to be primitive.

That this view is generally false is well known to anthropologists, and it is interesting to see the actual figures for hours worked by different communities. Gerald Leach, in his painstaking report 'Energy and food production' shows that hunter-gathers like the ! Kung bushmen of the Kalahari desert in South Africa spend less than a quarter of the 'working week' gathering food, and much of this is hardly a strenuous activity. They are mainly engaged in a leisurely stroll around the large area-over ten square kilometres a head-within which they can pick up their supplies of wild foods.

This idyllic situation was changed when arable crops were introduced by the first true farmers. Much more food was produced, and settlements of a greater density became possible. The cultivators, particularly at times of planting and harvest, had to do more work. Nevertheless, feeding a family with their own produce was hardly a full time job for subsistence farmers. The men at least had long hours for contemplation and recreation, even if they did some of the harder seasonal jobs like clearing secondary bush after a period of fallow. Even the women only worked in the field intermittently, though their elaborate procedures for preparing food kept them busy (and out of mischief) for long hours. Only when the peasants had to produce more food than they could eat, to sell

\section{Self-sufficiency on one-tenth of an acre}

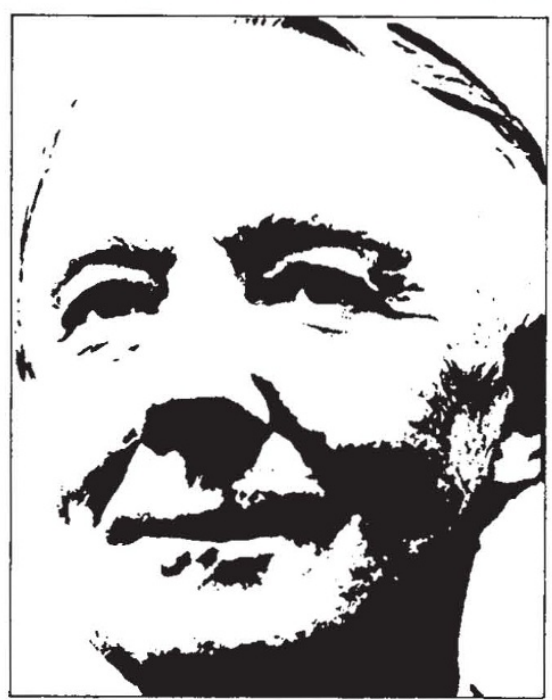

KENNETH MELLANBY

to pay taxes or to buy luxuries, did they begin to work really hard.

Today in most western countries we find substantial numbers of people with the urge to become self sufficient, often as a protest at the rat race of modern civilisation. Some work alone, some in family groups, some in communes. Few succeed, and most seem to demonstrate the truth of the text quoted in my first paragraph. They sweat over their toil, and fail to produce the food they need. This is partly because many lack the necessary training in farming and gardening, and waste much of their effort. But generally failure is the result of trying to do too much. To be really self-sufficient on a few acres of poor ground, when this means not only producing adequate food but also selling produce to provide something approaching an urban standard of living, is not an easy task.

But if they emulate the ! Kung bushmen, who only wished to eat, the situation could be quite different. There should be little difficulty in producing enough food for a healthy diet, though many items we now eat would not be available. If a single man were prepared to obtain three quarters of his food as wheat, he could grow the required amount ( $200 \mathrm{~kg}$ for a yearly ration) on an area of about one twentyfifth of a hectare. Using modern farming techniques this could be planted, fertilised, sprayed and harvested in about half an hour per annum. Even with hand labour, digging with a spade and harvesting with a sickle, one or two weeks of hard work should suffice. $\mathrm{He}$ would not have a complete diet, but if he kept a few hens, growing a few more square metres of corn to feed them, allowed his nanny goat to browse on the roadside verges, and did a bit of hunting gathering for wild produce, he could live quite well and still have as much leisure as the fortunate bushman. Trouble would only arise when he began to hanker after the delights of the civilisation he had abandoned. 